www.jmscr.igmpublication.org

Impact Factor 5.84

Index Copernicus Value: 71.58

ISSN (e)-2347-176x ISSN (p) 2455-0450

crossref DOI: _https://dx.doi.org/10.18535/jmscr/v5i12.34

Journal Of Medical Science And Clinical Research

IGM Publication

An Official Publication of IGM Publication

\title{
Preoperative Predictors for Conversion in Laparoscopic Cholecystectomy
}

\author{
Authors \\ Prof Dr Braja Mohan Mishra ${ }^{1}$, Dr A.N Behera ${ }^{2}$, Dr Ravi Kumar Jha ${ }^{3}$ \\ ${ }^{1}$ Prof and HOD, ${ }^{2}$ Associate Prof, ${ }^{3}$ Post Graduate Student \\ Department Of General Surgery, Vimsar, Burla , Sambalpur, Odisha, India, Pin: 768017 \\ Email: umailravijha03@gmail.com, Mob no.7540886610
}

\begin{abstract}
Introduction: Laparoscopic cholecystectomy has rejuvenated general surgery and in very short time has become the gold standard operation for benign gallbladder disease, but the procedure is technically more demanding than the classical open cholecystectomy. Although introduction of laparoscopic cholecystectomy has dramatically affected the management of patients with biliary disease, but even today there are numerous challenges and unanswered questions that remain, regarding issues related to application of laparoscopic techniques to this very common clinical disorder. Greater chances of damage to the common bile duct and surrounding viscera exist.

Aims and Objectives: The aim of our study was to evaluate some preoperative factors, which can reliably predict the chances of conversion to the open procedure and the complications during laparoscopic cholecystectomy. This may benefit the patients because beforehand information about the possibility of complications and conversion to the open procedure can be made available. The patient can be mentally prepared and can adjust his or her expectations accordingly. In addition, the surgeon can directly perform the classical open cholecystectomy in the patients with presumed difficult surgery thus saving operating time and the conversion rate.

Material and Methods: This prospective study was conducted on 250 patients undergoing laparoscopic cholecystectomy in the department of Surgery, VIMSAR, BURLA, and over a period of 24 months from november 2015 to november 2017, to evaluate and correlate the clinical, biochemical and ultrasonographic findings with the operative findings for anticipating difficult laparoscopic cholecystectomy. The parameters which were studied are age $\geq 65$ years, sex, acute cholecystitis, number of acute attacks in the past, history of upper abdominal surgery, WBC count ( $\geq 10000)$, total bilirubin $(\geq 1.5 \mathrm{mg} / \mathrm{dl}), A L P(\geq 310 \mathrm{IU} / \mathrm{L})$, gallbladder wall thickness $(\geq 4 \mathrm{~mm})$, pericholecystic collection, gallbladder size (contracted gallbladder), stone impaction at neck/cystic duct and Mirizzi's syndrome.

The risk of organ injury was minimized in our study by using open trocar placement (a Hasson cannula was used). Patients with previous lower abdominal surgeries were also included in our study.

The operative parameters taken to assess the difficulty of the laparoscopic cholecystectomy were total time taken to operate from the insertion of the trocar to the extraction of the gallbladder (more than 90 mins), tear of gallbladder with spillage of bile and stones, and conversion to open cholecystectomy. The surgeons experienced in laparoscopic cholecystectomy performed the surgeries.

Results: In this study the rate of conversion was found to be 7.2\%, Male to female ratio was 1:5.62. The majority of patients were in the age group of 41 - 50 years. The mean age was 41.9 with standard deviation
\end{abstract}


of 9.9. The conversion rate is highest in the age group of $51-60$ years. Overall 46 out of 250 patients were predicted to be difficult cases based on clinical parameters out of which 30 were difficult on surgery and 18 out of the 46 cases got converted. Out of 250 patients 13 patients were predicted to be difficult based on biochemical parameters of which 10 were difficult on surgery. Out of 10 difficult cases 4 got converted to open procedure. Out of 250 patients 30 were predicted to be difficult of which 23 were found to be difficult on ultrasonographic parameters. Out of these 23 difficult cases 13 got converted to open procedure. In this study, on multivariate logistic regression analysis male sex, acute cholecystitis, WBC more than 10000/ cumm, contracted gallbladder and stone impaction at neck region were found to be significant predictive factors for conversion of laparoscopic cholecystectomy to open cholecystectomy. Most common reason for difficult laparoscopic cholecystectomy and conversion to open procedure was adhesions in the Calot's triangle and with the surrounding structures. The intra-operative complications that occurred in this study were cystic artery tear, bleeding from gallbladder bed, tear of gallbladder and spillage of stones and bile.

Conclusion: From this study, we can conclude that preoperative clinical, biochemical and ultrasonographic parameters are good predictors of difficulty in laparoscopic cholecystectomy in the majority of cases and should be used as a screening procedure. It can help surgeons to get an idea of the potential difficulty to be faced in a particular patient.

\section{Introduction}

Cholecystectomy is the most common elective procedure performed on the biliary tract and the second most common abdominal operation performed today. ${ }^{1}$ Over the past years, removal of gall bladder has been the primary mode of therapy for gall stone disease. Alternative modes include gall bladder dissolving agents, biliary lithotripsy and percutaneous cholecystolithotomy. The main disadvantage with these techniques is that the stone forming organ i.e gall bladder is left in situ resulting in recurrence.

With more and more endeavors being made in the field of laparoscopy, more and more complicated cases which were relatively contraindicated a few years ago are now being tackled laparoscopically. However one should be very careful in the cases with complicated gallstone disease to avoid any disastrous complication. Safe dissection is the key to complete laparoscopic cholecystectomy successfully. Every case should be considered as difficult until completed successfully. Level of difficulty may vary with the skill and experience of the surgeon. An inexperienced surgeon ascending the learning curve may find conditions like intra abdominal adhesions, acutely inflamed friable gall bladder, gangrenous gall bladder and fibrotic Calot's triangle to be of insurmountable difficulty. However some conditions are really difficult to tackle irrespective of the experience and skill of the surgeon. Though there is no consistent definition for difficult Laparoscopic cholecystectomy, many studies have considered Laparoscopic cholecystectomy to be difficult when we encounter 1) dense adhesions at the triangle of Calot's (frozen triangle of Calot's prohibiting proceeding laparoscopically without risk), 2) contracted and fibrotic gallbladder, 3) previous upper abdominal surgery, 4) gangrenous gallbladder, 5) acutely inflamed gallbladder, 6) empyema gallbladder including Mirizzi's syndrome 7) previous cholecystostomy and 8) cholecystogastric or cholecystoduodenal fistula. $^{2,14}$

Access to the peritoneal cavity to create the pneumoperitoneum may be difficult in the previously operated cases. In such cases, creating pneumoperitoneum by open technique or use of veress needle through the Palmer's point $(2 \mathrm{~cm}$ below the left costal margin in the mid clavicular line) may be the useful alternatives to the umbilical point.

The safest entry can be made into the peritoneal cavity by adhering to the basic principle of lifting the anterior abdominal wall with the help of two towel clips placed on the either side of umbilical incision into the rectus sheath and then pushing the spring loaded veress needle through the sheath. 
Anatomic variations in the cystic duct and hepatic ducts are common. This variation should be bourne in mind during dissection of the hepatocystic Triangle.

Laparoscopic cholecystectomy may need conversion in the following conditions:
1. Unclear anatomy
2. Failure to progress in dissection
3. Injury to major blood vessel
4. Injury to abdominal viscous
5. Injury to bile duct
6. Doubtful pathology

A recent report emphasizes the fact that the outcome of the patient is not influenced by the rank of the surgeon performing the surgery. ${ }^{15}$ However, the consensus has been that every surgeon has to undergo a learning curve for the laparoscopic procedure and develop his dexterity in laparoscopy. ${ }^{2-14}$

In spite of increasing expertise and advances in technology, conversion rate is still 1.5 to $35 \%$ in different centers. ${ }^{2-14}$ This conversion is neither a failure nor a complication, but an attempt to avoid complications. Conversion from laparoscopic to open cholecystectomy is required when safe completion of the laparoscopic procedure cannot be ensured. The identification of parameters predicting conversion would be useful to improve preoperative patient counseling, provide for better perioperative planning, optimize operating room efficiency, and to avoid laparoscopic- associated cost \& complications by performing an open operation when appropriate.

This study has been conducted on certain clinical and investigation parameters to look for their reliability as predictors of difficult laparoscopic cholecystectomy.

\section{Aims and Objectives}

Pre-operative prediction of difficult laparoscopic cholecystectomy using clinical, biochemical \& ultrasonographic parameters.

\section{Materials and Methods}

1) Study Area: Department of General Surgery
2) Study Population: All patients admitted for laparoscopic cholecystectomy

3) Study Period: November 2015 to November 2017

4) Sample Size: 250 patients

5) Sample Design: All indoor patients admitted for laparoscopic cholecystectomy during the study period

\section{Inclusion Criteria}

All patients with symptomatic gall stone disease admitted for laparoscopic cholecystectomy.

\section{Exclusion Criteria}

- Patients with common bile duct stone

- Patients with known carcinoma GB

- Acute cholecystitis more than 72 hours

- Patients with history of cholangitis

- Combined with other surgeries

- ASA score III/IV

- Instrument failure

6) Study Design: Descriptive prospective crosssectional study

7) Parameters Studied: The following parameters of the study sample was studied to predict a difficult laparoscopic cholecystectomy:

- Age

- Sex

- Present acute attack

- Number of attacks

- Past upper abdominal operation

- Total \& differential WBC count

- Alkaline phosphatise levels

- Total bilirubin

- USG findings

Age $\geq 65$ Yrs, Male gender, Acute cholecystitis, $\geq$ 2 previous acute attacks, past upper abdominal surgery, $\mathrm{WBC} \geq 10000 /$ cumm, raised alkaline phosphatase > $310 \mathrm{IU} / \mathrm{L}$, raised total bilirubin > $1 \mathrm{mg} / \mathrm{dl}$ and USG findings of pericholecystic fluid collection, GB wall thickness $\geq 4 \mathrm{~mm}$, contracted GB, stone impaction at neck/cystic duct, Mirizzi's syndrome were considered as predictors of difficult laparoscopic cholecystectomy in this study. Cases which got converted to open 
cholecystectomy were considered as difficult cases.

\section{8) Study Tools}

- Predesigned pretested schedule

- Laboratory reports

- Abdominal USG reports

- Individual patient file

- Discharge certificates

9) Study Techniques: The indoor patients admitted for laparoscopic cholecystectomy were included in this study. Informed consent was taken from the sample group after explanation and before inclusion into the study. Then after interviewing the patient a predesigned pretested schedule as given in the annexure was filled in.

10) Plan for Analysis of Data: The collected data was compiled in a Microsoft Excel sheet, and subsequently suitable multivariate logistic regression analysis using SPSS 16.0 version was done accordingly with different appropriate statistical methods.

\section{Results and Analysis}

A series of 250 cases undergoing laparoscopic cholecystectomy for gall stone disease were selected for study. All the cases were predicted to be either difficult or easy for laparoscopic cholecystectomy based on preoperative clinical, biochemical and USG parameters. Causes of conversion to open cholecystectomy were assessed and analysed both preoperatively and peroperatively. Results of the study were analysed as follows:-

\section{1) Total incidence of conversion}

\section{Table- I}

\begin{tabular}{|l|c|c|}
\hline $\begin{array}{l}\text { Total no of } \\
\text { cases }\end{array}$ & No of conversion & Percentage \\
\hline 250 & 18 & 7.2 \\
\hline
\end{tabular}

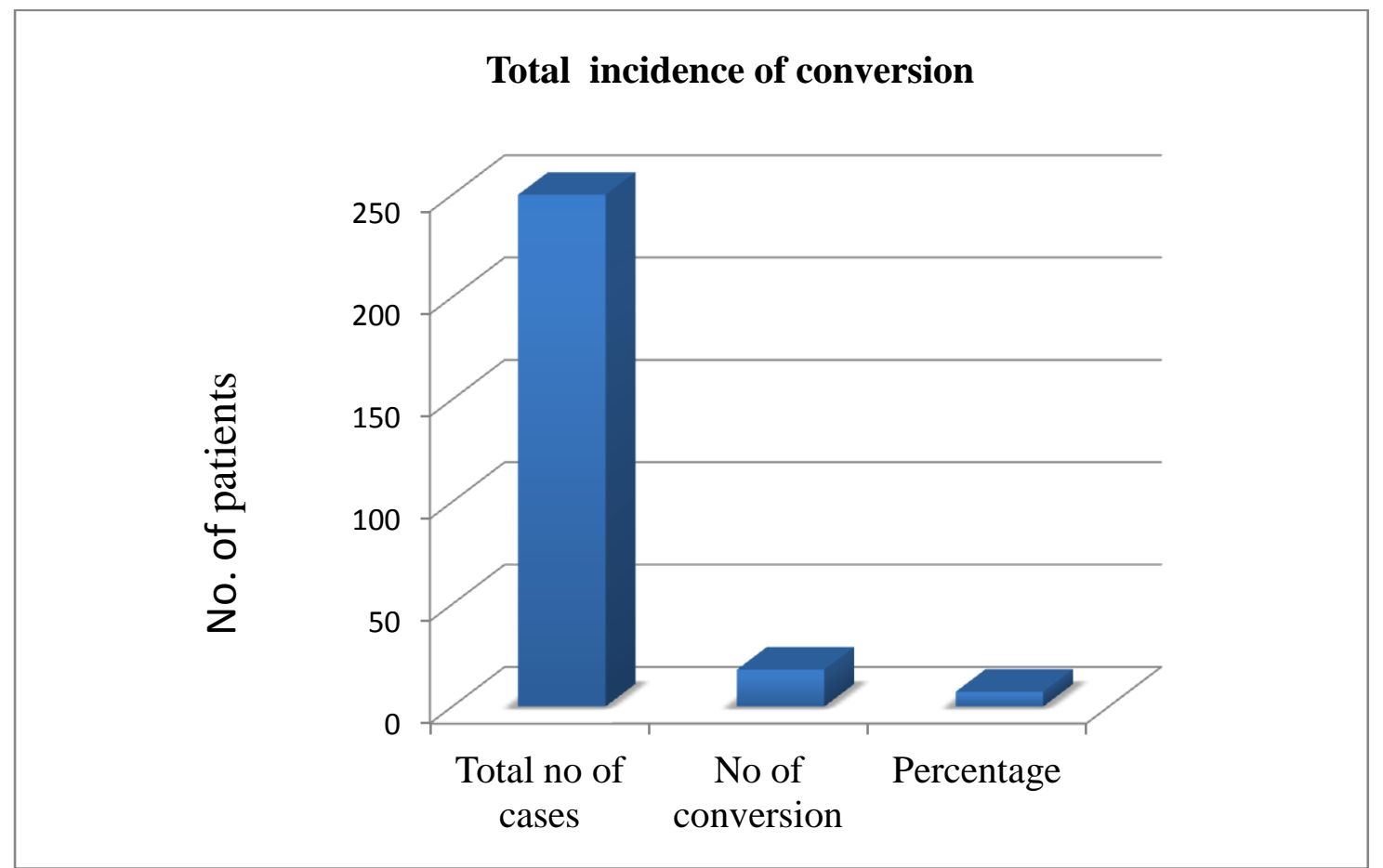

In this study a case series of 250 patients who Table - II

underwent laparoscopic cholecystectomy were prospectively analysed. Laparoscopic cholecystectomy was successfully carried out in 232 patients and 18 patients needed conversion to open cholecystectomy. Rate of conversion was $7.2 \%$.

\section{2) Age distribution}

\begin{tabular}{|l|c|c|}
\hline Age & No of patients $(\%)$ & No of conversions $(\%)$ \\
\hline $21-30$ & $39(15.6)$ & $2(0.8)$ \\
\hline $31-40$ & $70(28)$ & $2(0.8)$ \\
\hline $41-50$ & $95(38)$ & $3(1.2)$ \\
\hline $51-60$ & $42(16.8)$ & $7(2.8)$ \\
\hline $61-70$ & $3(1.2)$ & $3(0.8)$ \\
\hline $70-80$ & $1(0.4)$ & $1(0.4)$ \\
\hline Total & 250 & $18(7.2)$ \\
\hline
\end{tabular}




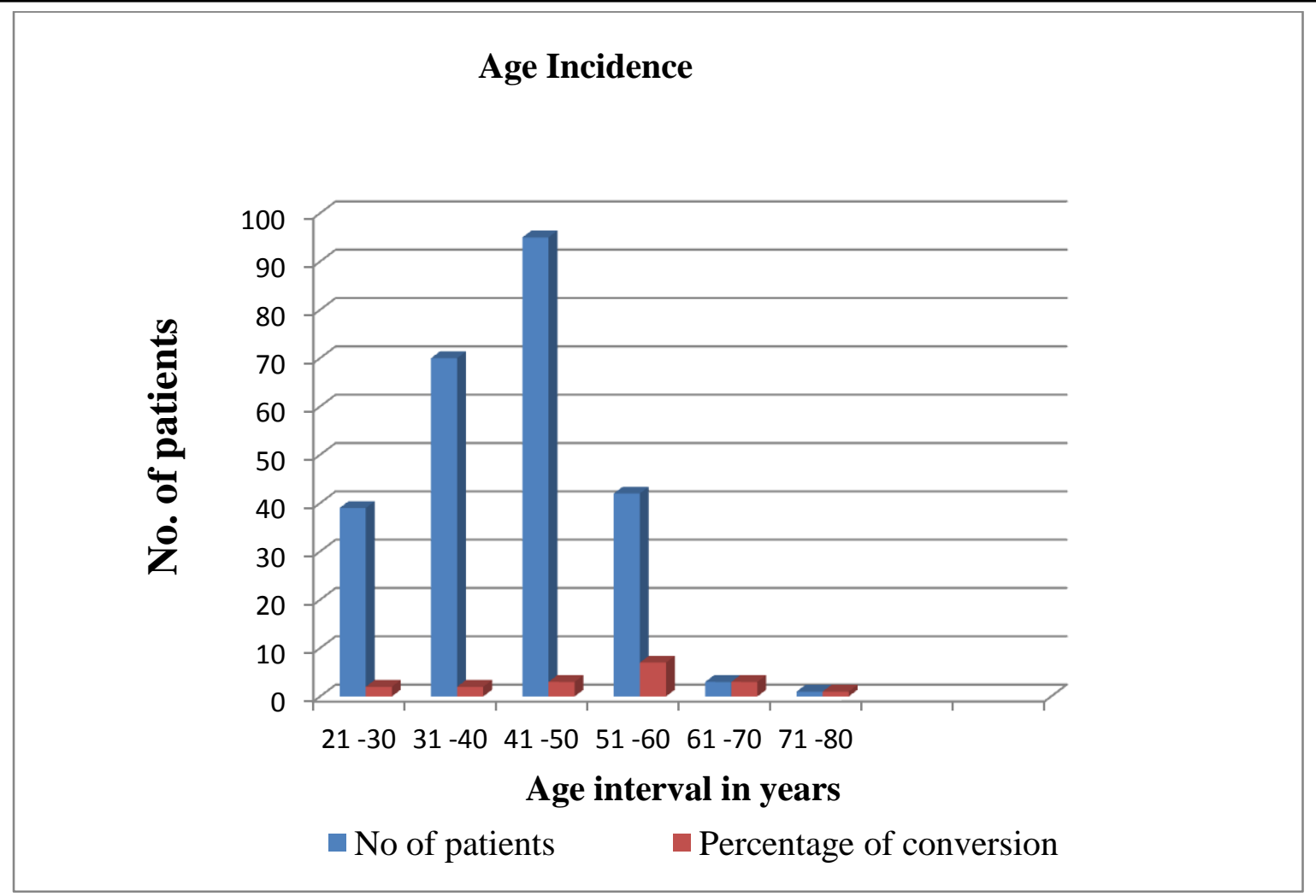

In the series of 250 cases the age of patients varied from range of $21-74$ years. The majority of patients were in the age group of $41-50$ years. The mean age was 41.9 with standard deviation of 9.9. The conversion rate is highest in the age group of $51-60$ years. The conversion rate in the age group of $\geq 60$ years in this study is $100 \%$. So it is observed that with increasing age risk of conversion increases.

\section{3) Sex Ratio}

Table - III

\begin{tabular}{|l|c|c|}
\hline & $\begin{array}{c}\text { Number of Patients } \\
(\%)\end{array}$ & $\begin{array}{c}\text { Number of } \\
\text { Conversion (\%) }\end{array}$ \\
\hline Male & $39(15.6)$ & $8(3.2)$ \\
\hline Female & $219(84.4)$ & $10(4.0)$ \\
\hline Total & 250 & $18(7.2)$ \\
\hline
\end{tabular}

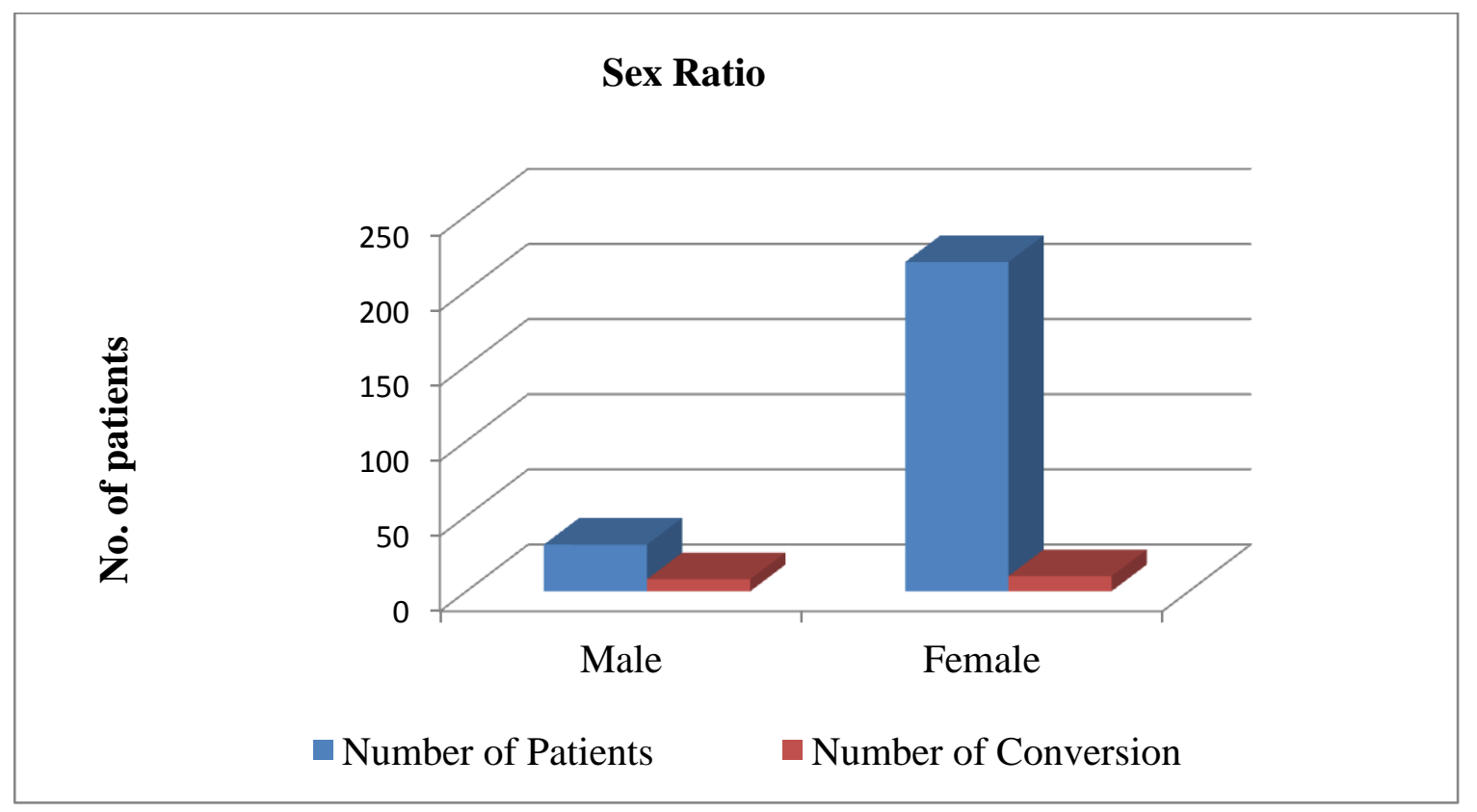


Out of 250 patients, 39 were male and 219 were female. Male: Female $=1$ : 5.62. Out of 18 converted patients 8 (3.2\% of 250$)$ were males and 10 (4\% of 250) were female patients. Out of 39 male patients 8 got converted which accounts for $20.5 \%$ of male patients whereas out of 219 females 10 got converted which accounts for $4.5 \%$ of female patients. From this we can conclude that conversion rate is 4.5 times higher in male patients in this study.

\section{4) Acute Cholecystitis}

\section{Table - IV}

\begin{tabular}{|l|c|c|}
\hline & $\begin{array}{c}\text { Number of } \\
\text { Patients }(\%)\end{array}$ & $\begin{array}{c}\text { Number of } \\
\text { conversion }(\%)\end{array}$ \\
\hline Male & $4(1.6)$ & $2(0.8)$ \\
\hline Female & $7(2.8)$ & $1(0.4)$ \\
\hline Total & $11(4.4)$ & $(1.2)$ \\
\hline
\end{tabular}

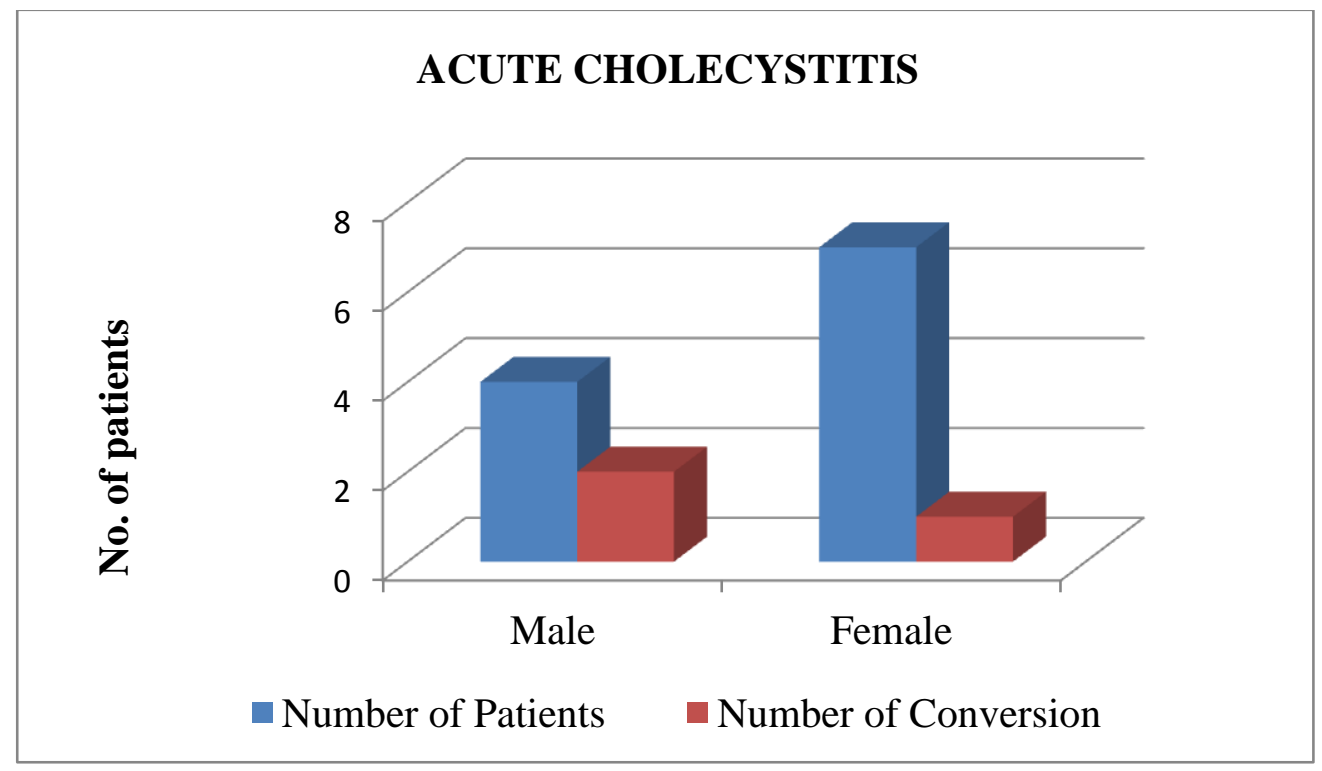

Out of 11 patients who presented with acute cholecystitis 4 were male and 7 female. Among these 2 male patients and 1 female patient got converted to open cholecystectomy. Overall 3 out of $11(27.27 \%$ of 11$)$ patients got converted.
5) No of Acute attacks $(\geq 2)$

\section{Table - V}

\begin{tabular}{|l|c|c|}
\hline & Number of Patients & Number of Conversion \\
\hline Male & 7 & 2 \\
\hline Female & 3 & 2 \\
\hline Total & 10 & 4 \\
\hline
\end{tabular}

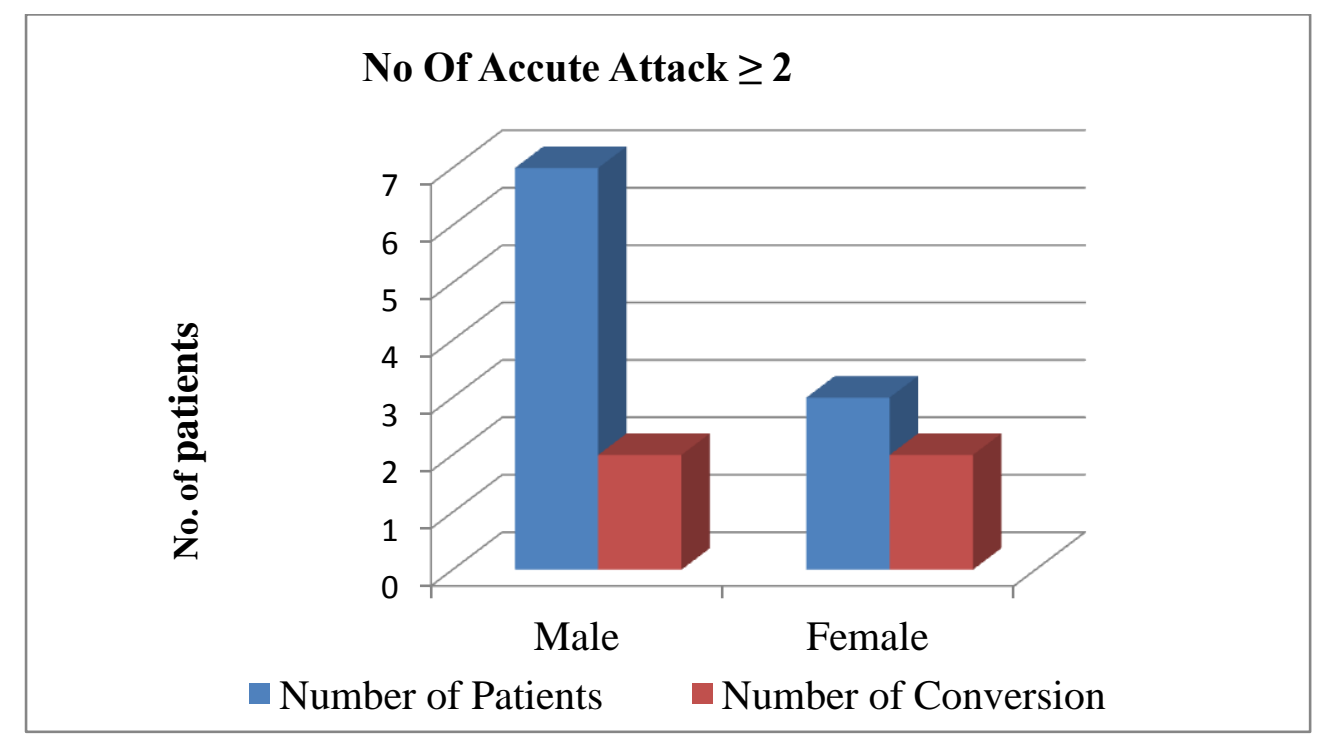




\section{JMSCR Vol||05||Issue||12||Page 31426-31440||December}

Out of 250 patients 10 had $\geq 2$ acute attacks of which 7 (2 conversions) were male and 3 (2 conversions) female. $40 \%$ (4 out of 10) of the patients with $\geq 2$ acute attacks got converted.

\section{6) History of Upper Abdominal Surgery}

Table- VI

\begin{tabular}{|l|c|c|}
\hline & $\begin{array}{c}\text { Number of } \\
\text { Patients }\end{array}$ & $\begin{array}{c}\text { Number of } \\
\text { Conversion }\end{array}$ \\
\hline Male & 1 & 1 \\
\hline Female & 0 & 0 \\
\hline Total & 1 & 1 \\
\hline
\end{tabular}

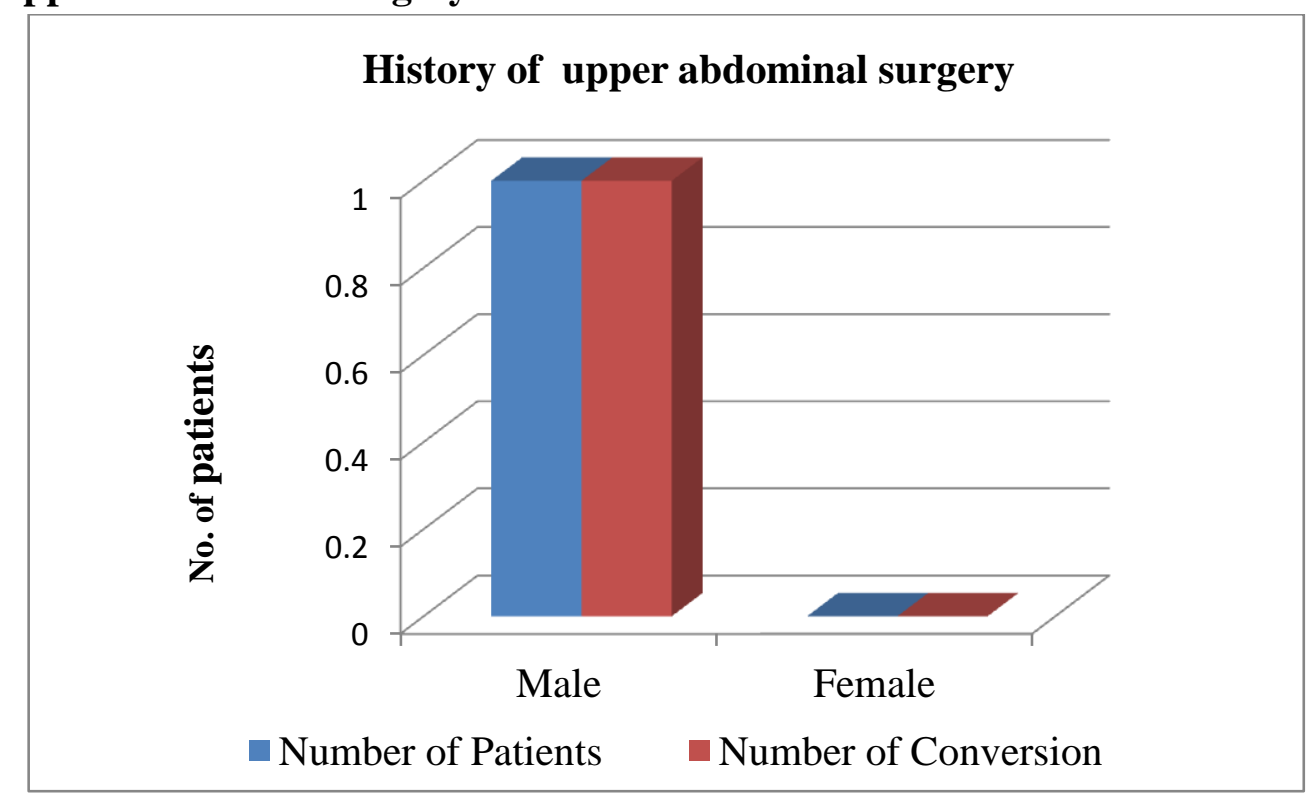

Out of 250 patients only 1 male patient had history of upper abdominal operation which got converted due to dense adhesions.

White Blood Cell $\geq 10000 /$ cumm

\section{Table-VII}

\begin{tabular}{|l|c|c|}
\hline & $\begin{array}{c}\text { Number of } \\
\text { patients }\end{array}$ & $\begin{array}{c}\text { Number of } \\
\text { conversion }(\%)\end{array}$ \\
\hline Male & 4 & $2(0.8)$ \\
\hline Female & 6 & $1(0.4)$ \\
\hline Total & 10 & $3(1.2)$ \\
\hline
\end{tabular}

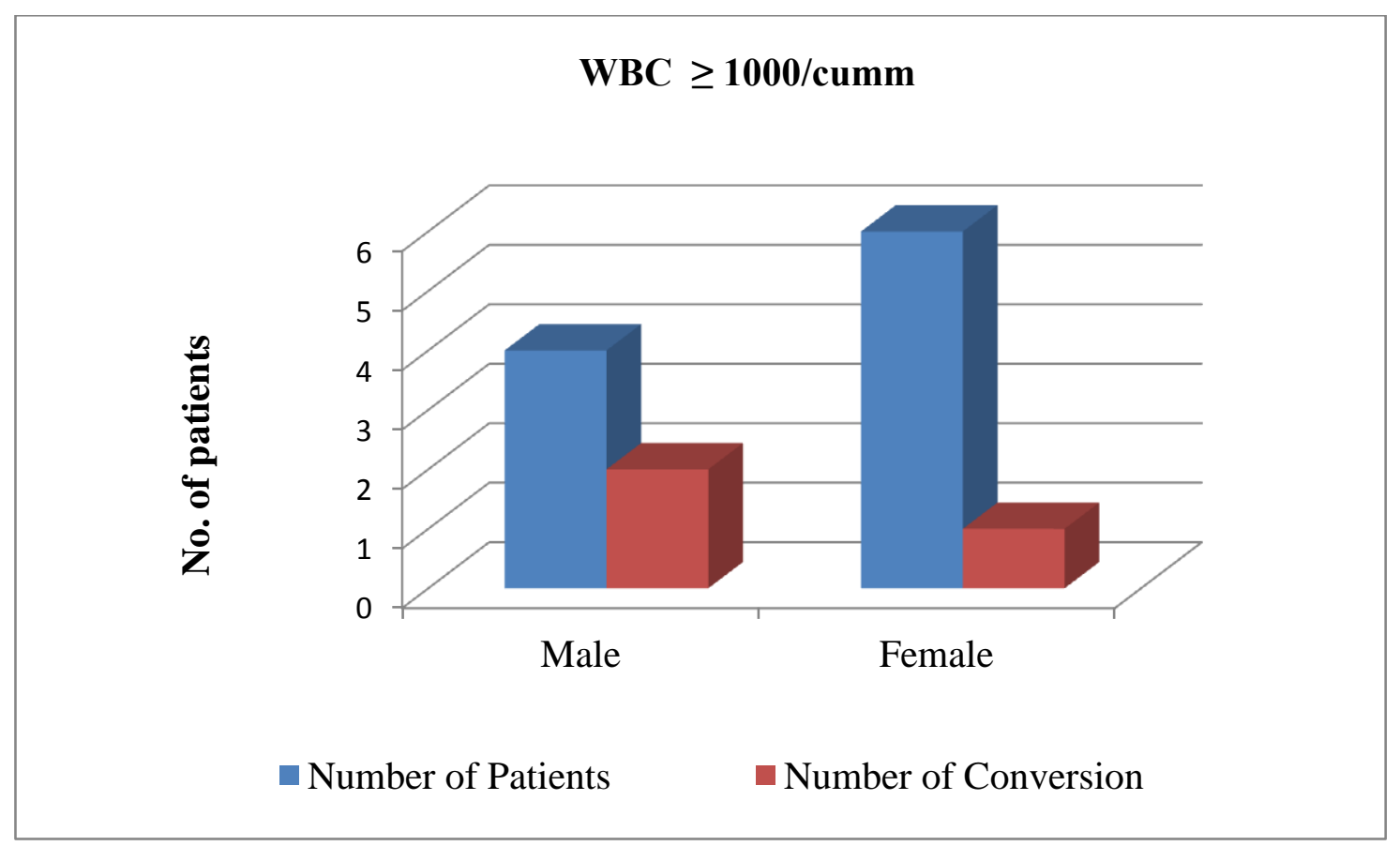




\section{JMSCR Vol||05||Issue||12||Page 31426-31440||December}

Out of 250 patients $10 \mathrm{had} \mathrm{WBC} \geq 10000 \mathrm{cu} / \mathrm{mm}$ of which 3 (1.2\% of 250$)$ patients got converted to open cholecystectomy.

8) Gall Bladder Wall Thickness $\geq 4 \mathrm{~mm}$
Table-VIII

\begin{tabular}{|l|c|c|}
\hline & $\begin{array}{c}\text { Number of } \\
\text { Patients }\end{array}$ & $\begin{array}{c}\text { Number of } \\
\text { Conversions (\%) }\end{array}$ \\
\hline Male & 2 & $2(0.8)$ \\
\hline Female & 3 & $2(0.8)$ \\
\hline Total & 5 & $4(1.6)$ \\
\hline
\end{tabular}

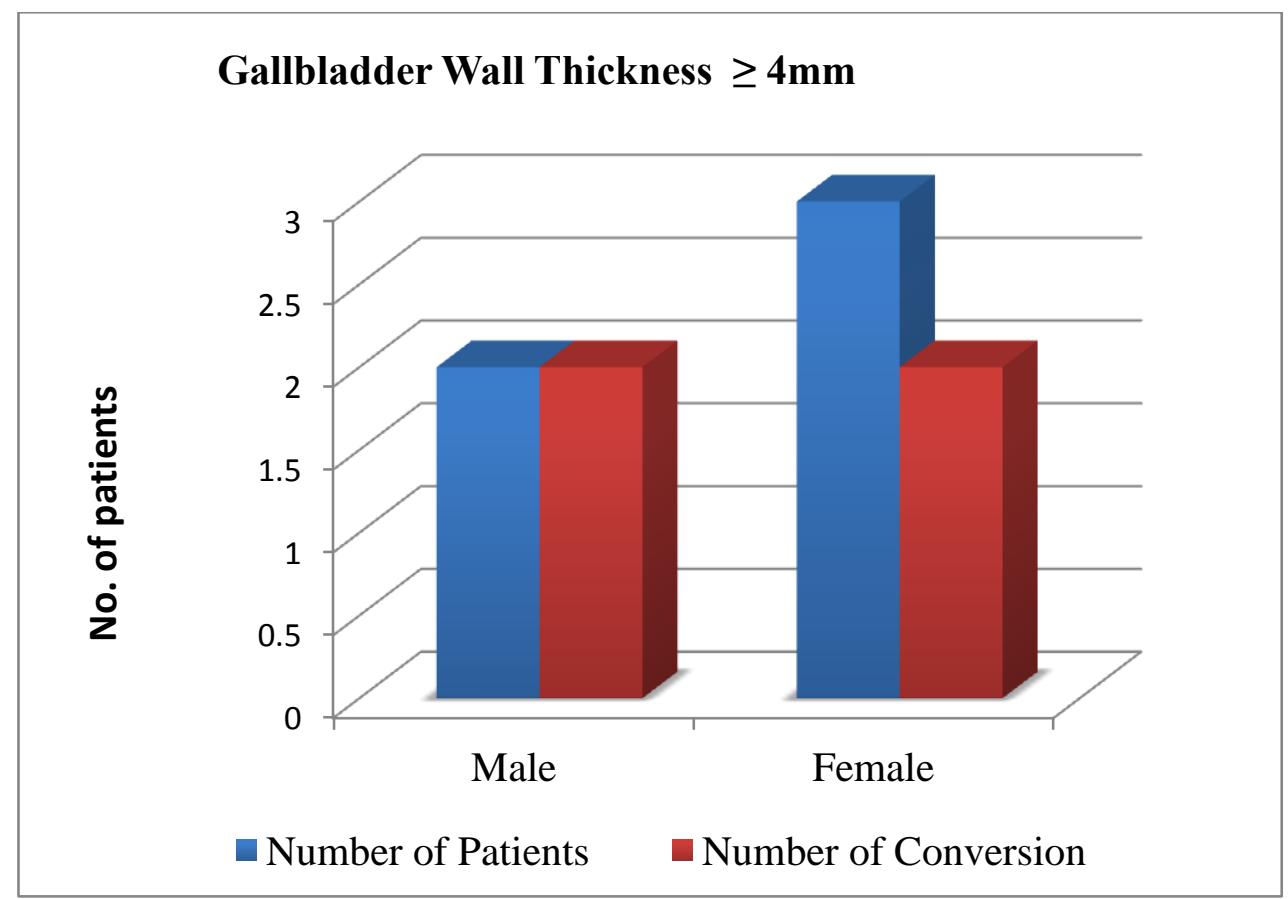

Out of 250 patients 5 had GB wall thickness $\geq$ Table-IX $4 \mathrm{~mm}$ of which $4(1.6 \%)$ got converted to open cholecystectomy.

9) Contracted gallbladder

\begin{tabular}{|l|c|c|}
\hline & $\begin{array}{c}\text { Number of } \\
\text { Patients (\%) }\end{array}$ & $\begin{array}{c}\text { Number of } \\
\text { Conversion (\%) }\end{array}$ \\
\hline Male & $10(4.0)$ & $5(2.0)$ \\
\hline Female & $11(4.4)$ & $5(2.0)$ \\
\hline Total & $21(8.4)$ & $10(4.0)$ \\
\hline
\end{tabular}

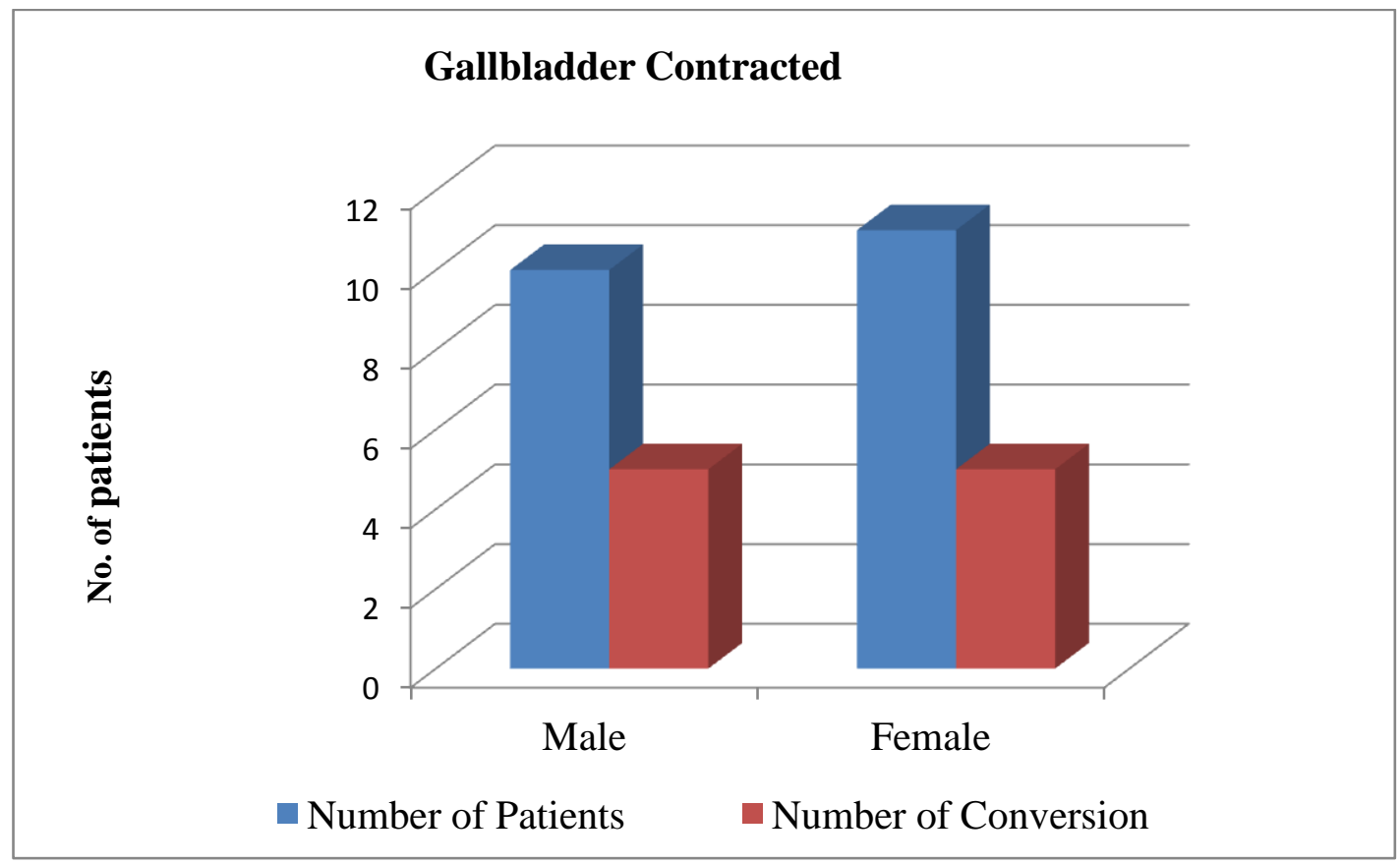




\section{JMSCR Vol||05||Issue||12||Page 31426-31440||December}

Out of 250 patients $21(8.4 \%)$ had contracted GB of which $10(4.0 \%)$ got converted to open cholecystectomy.

\section{0) Stone Impacted at Neck/Cystic Duct:}

Table $-\mathbf{X}$

\begin{tabular}{|l|c|c|}
\hline & $\begin{array}{c}\text { Number of } \\
\text { Patients }\end{array}$ & $\begin{array}{c}\text { Number of } \\
\text { Conversions }\end{array}$ \\
\hline Male & 3 & 1 \\
\hline Female & 6 & 1 \\
\hline Total & 9 & 2 \\
\hline
\end{tabular}

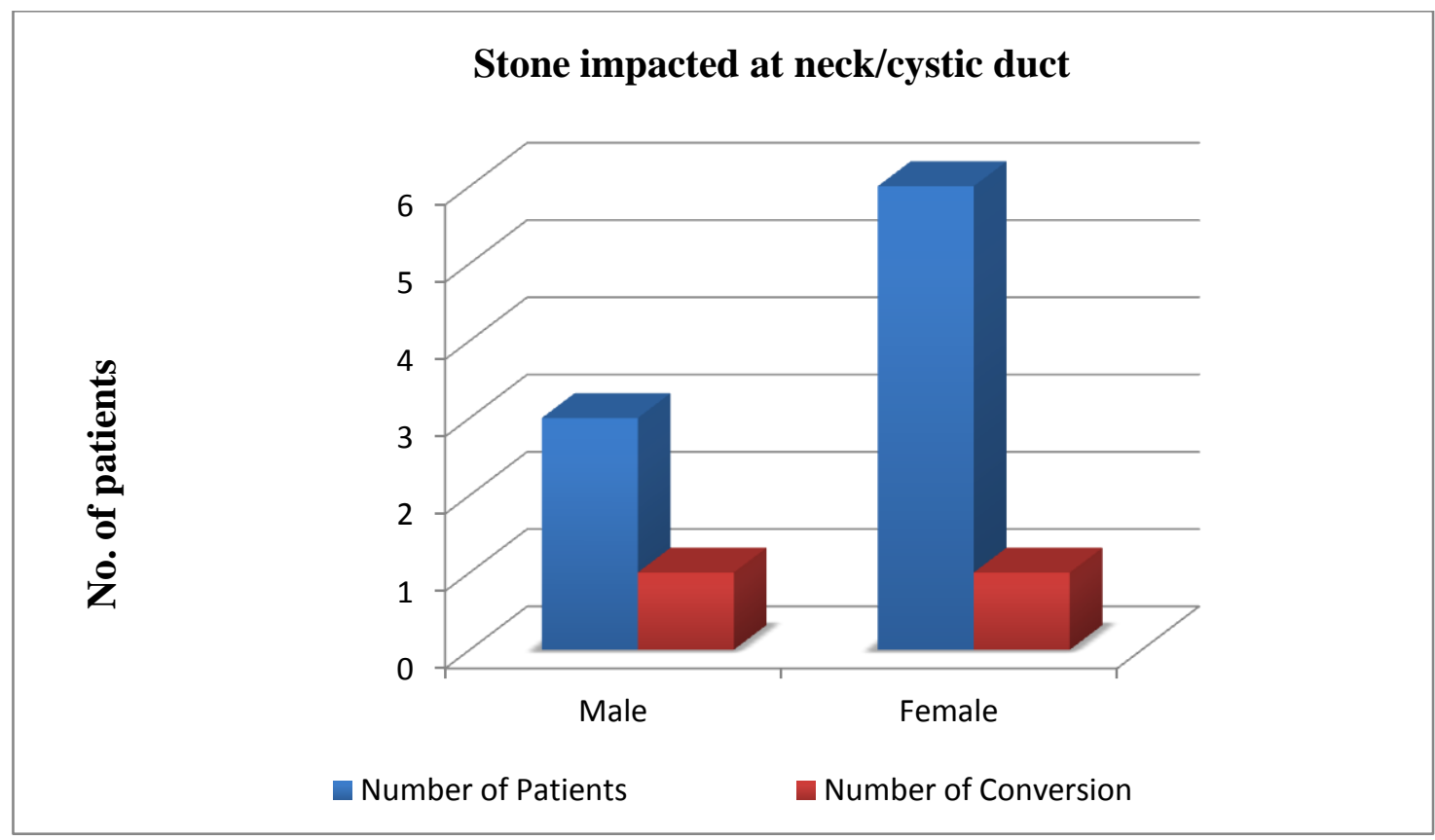

Out of 250 patients 9 had stone impacted at Table-XI

neck/cystic duct on USG of which 2 got converted to open cholecystectomy.

11) Peroperative causes of conversion

\begin{tabular}{|l|c|}
\hline Peroperative causes of conversion & $\begin{array}{c}\text { No. of } \\
\text { conversions (\%) }\end{array}$ \\
\hline Dense adhesions around Calot's triangle & $7(38.88 \%)$ \\
\hline Anatomic variation of cystic duct & $1(5.55 \%)$ \\
\hline Uncontrolled bleeding pouch with & $3(16.66 \%)$ \\
\hline $\begin{array}{l}\text { Distended Hartman's } \\
\text { adhesions }\end{array}$ & $2(11.11 \%)$ \\
\hline Contracted GB & $3(16.66 \%)$ \\
\hline Wide and short cystic duct & $2(11.11 \%)$ \\
\hline Total cases converted & $18(100 \%)$ \\
\hline
\end{tabular}

\section{Peroperative causes of conversion}

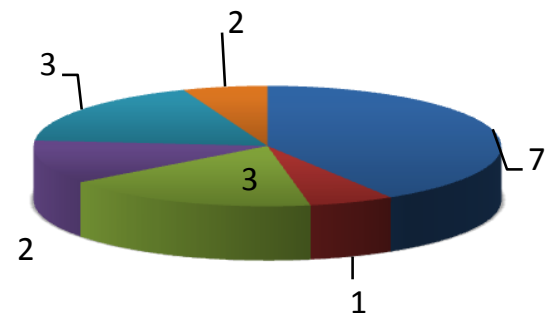

Dense adhesions around gallbladder obscuring Calot's triangle - Anatomical Variation Of Cystic Duct With Distortion Of Calot's Triangle Uncontrolled bleeding

- Distended hartman's pouch and dense adhesion

- Contracted GB

Wide Short Dilated Cystic Duct 
In the study of 250 cases, 18 cases were converted to open cholecystectomy. Causes of peroperative conversion were as given above.

\section{2) Preoperative prediction with clinical parameters:}

\section{Table-XI}

\begin{tabular}{|l|c|c|c|}
\hline Preoperative parameters & $\begin{array}{c}\text { Predicted } \\
\text { as difficult }\end{array}$ & $\begin{array}{c}\text { Concluded } \\
\text { as difficult }\end{array}$ & $\begin{array}{c}\text { Conver } \\
\text { sion }\end{array}$ \\
\hline Clinical & 46 & 30 & 18 \\
\hline Age ( $\geq 65$ years $)$ & 4 & 4 & 4 \\
\hline Sex ( Male ) & 31 & 19 & 8 \\
\hline Acute cholecystitis & 11 & 7 & 3 \\
\hline No of acute attack( $\geq 2)$ & 10 & 10 & 4 \\
\hline H/o upper abd. surgery & 1 & 1 & 1 \\
\hline
\end{tabular}

Overall 46 out of 250 patients were predicted to be difficult cases out of which 30 were difficult on surgery and 18 out of all difficult cases got converted.

\section{3) Preoperative prediction with biochemical parameters}

\section{Table-XIII}

\begin{tabular}{|l|c|c|c|}
\hline $\begin{array}{l}\text { Preoperative } \\
\text { parameters }\end{array}$ & $\begin{array}{c}\text { Predicted } \\
\text { as difficult }\end{array}$ & $\begin{array}{c}\text { Concluded } \\
\text { as difficult }\end{array}$ & Conversion \\
\hline Biochemical & 13 & 10 & 4 \\
\hline $\begin{array}{l}\text { WBC }(\geq \\
10000 / \text { cumm })\end{array}$ & 10 & 7 & 3 \\
\hline $\begin{array}{l}\text { Total Bilirubin } \\
(\geq 1 \mathrm{mg} / \mathrm{dl})\end{array}$ & 1 & 1 & 0 \\
\hline ALP $(>310 \mathrm{IU} / \mathrm{L})$ & 2 & 2 & 1 \\
\hline
\end{tabular}

Out of 250 patients 13 patients were predicted to be difficult based on biochemical parameters of which 10 were difficult on surgery. Out of 10 difficult cases 4 got converted to open procedure.

\section{4) Preoperative prediction with USG parameters}

Table- XIV

\begin{tabular}{|l|c|c|c|}
\hline $\begin{array}{l}\text { Preoperative } \\
\text { parameters }\end{array}$ & $\begin{array}{c}\text { Predicted } \\
\text { as difficult }\end{array}$ & $\begin{array}{c}\text { Concluded } \\
\text { as difficult }\end{array}$ & Conversion \\
\hline Ultrasonography & 30 & 23 & 13 \\
\hline $\begin{array}{l}\text { Pericholecystic } \\
\text { collection }\end{array}$ & 1 & 1 & 1 \\
\hline $\begin{array}{l}\text { GB wall thickness ( } \\
\geq 4 \mathrm{~mm})\end{array}$ & 5 & 4 & 4 \\
\hline $\begin{array}{l}\text { Stone impaction at } \\
\text { neck }\end{array}$ & 9 & 7 & 2 \\
\hline Mirizzi's syndrome & 1 & 1 & 0 \\
\hline GB contracted & 21 & 17 & 10 \\
\hline
\end{tabular}

Out of 250 patients 30 were predicted to be difficult of which 23 were found to be difficult on laparoscopic cholecystectomy. Out of these 23 difficult cases 13 got converted to open procedure. There were 5 cases with GB wall thickness $\geq$ $4 \mathrm{~mm}$ of which 4 were found to be difficult on surgery and were converted to open procedure. Out of 9 cases of stone impaction at neck/cystic duct 7 were predicted to be difficult of which 2 were converted to open procedure. There were 21 cases of contracted GB out of 17 were difficult on surgery and 10 got converted to open procedure. There was only 1 case of Mirizzi's syndrome which was found to be difficult but did not need conversion.

15) Association of clinical findings with difficult laparoscopic cholecystectomy using multivariate logistic regression analysis

Table-XV

\begin{tabular}{|c|c|c|c|}
\hline $\begin{array}{c}\text { Clinical } \\
\text { parameters }\end{array}$ & $\begin{array}{l}\text { Odds } \\
\text { ratio } \\
(\mathrm{OR})\end{array}$ & $\begin{array}{c}95 \% \mathrm{CI} \\
\text { OR }\end{array}$ & $\mathrm{p}$ value \\
\hline \multirow{2}{*}{$\begin{array}{l}\text { Age in years } \\
<65 \text { years } \\
\geq 65 \text { years }\end{array}$} & \multicolumn{3}{|c|}{ Reference } \\
\hline & NA & & $>0.05$ \\
\hline \multirow{2}{*}{$\begin{array}{c}\text { Sex } \\
\text { Female } \\
\text { Male }\end{array}$} & \multicolumn{3}{|c|}{ Reference } \\
\hline & 0.044 & $\begin{array}{c}0.013- \\
0.144\end{array}$ & 0.000 \\
\hline \multirow{2}{*}{$\begin{array}{c}\text { Acute } \\
\text { cholecystitis } \\
\text { No } \\
\text { Yes }\end{array}$} & \multicolumn{3}{|c|}{ Reference } \\
\hline & 0.021 & $\begin{array}{c}0.004- \\
0.111\end{array}$ & 0.000 \\
\hline \multirow{2}{*}{$\begin{array}{c}\text { No of acute } \\
\text { attacks } \\
<2 \\
\geq 2\end{array}$} & \multicolumn{3}{|c|}{ Reference } \\
\hline & \multicolumn{3}{|c|}{$\begin{array}{c}\mathrm{NA} \\
>0.05\end{array}$} \\
\hline \multirow{2}{*}{$\begin{array}{c}\text { H/o upper abd. } \\
\text { Surgery } \\
\text { No } \\
\text { Yes }\end{array}$} & \multicolumn{3}{|c|}{ Reference } \\
\hline & \multicolumn{3}{|c|}{$\begin{array}{c}\mathrm{NA} \\
>0.05\end{array}$} \\
\hline
\end{tabular}

The table above shows the male sex and acute cholecystitis to be the significant predictors of difficult laparoscopic cholecystectomy among the clinical parameters. 
16) Association of biochemical parameters with difficult laparoscopic cholecystectomy using multivariate logistic regression analysis

\section{Table- XVI}

\begin{tabular}{|l|c|c|c|}
\hline $\begin{array}{l}\text { Biochemical } \\
\text { parameters }\end{array}$ & $\begin{array}{c}\text { Odds ratio } \\
\text { ( OR })\end{array}$ & $\begin{array}{c}\text { 95\% CI } \\
\text { OR }\end{array}$ & $\mathrm{p}$ value \\
\hline \begin{tabular}{l} 
WBC \\
\multirow{2}{*}{$\begin{array}{l}\text { Normal } \\
\text { Raised }\end{array}$}
\end{tabular} & \multicolumn{3}{|c|}{ Reference } \\
\cline { 2 - 4 } $\begin{array}{l}\text { Total bilirubin } \\
(1 \mathrm{mg} / \mathrm{dl})\end{array}$ & 0.055 & $0.013-0.225$ & 0.000 \\
\hline $\begin{array}{l}\text { Alkaline } \\
\text { phospatase(310 } \\
\text { IU/L) }\end{array}$ & \multicolumn{2}{|c|}{ NA } & $>0.05$ \\
\hline
\end{tabular}

The above table shows only raised WBC count to be significant predictive factor among the biochemical parameters. Total bilirubin and alkaline phosphatase has $\mathrm{p}$ value $>0.05$ which is insignificant.

17) Association of USG parameters with difficult laparoscopic cholecystectomy using multivariate logistic regression analysis

Table- XVII

\begin{tabular}{|c|c|c|c|}
\hline USG parameters & $\begin{array}{l}\text { Odds } \\
\text { ratio } \\
(\text { OR ) }\end{array}$ & $\begin{array}{c}95 \% \mathrm{CI} \\
\text { OR }\end{array}$ & $\begin{array}{c}\mathrm{p} \\
\text { value }\end{array}$ \\
\hline \multirow{2}{*}{$\begin{array}{l}\text { tion in } \\
\text { duct } \\
\text { No } \\
\text { Yes }\end{array}$} & \multicolumn{3}{|c|}{ Reference } \\
\hline & 0.023 & $\begin{array}{c}0.004- \\
0.127\end{array}$ & 0.000 \\
\hline \multirow{2}{*}{$\begin{array}{l}\text { GB contracted } \\
\qquad \begin{array}{l}\text { No } \\
\text { Yes }\end{array}\end{array}$} & \multicolumn{3}{|c|}{ Reference } \\
\hline & 0.019 & $\begin{array}{c}0.005- \\
0.067\end{array}$ & 0.000 \\
\hline \multirow{2}{*}{$\begin{array}{r}\text { GB wall thickness } \\
<4 \mathrm{~mm} \\
\geq 4 \mathrm{~mm}\end{array}$} & \multicolumn{3}{|c|}{ Reference } \\
\hline & 0.052 & $\begin{array}{c}0.004- \\
0.765 \\
\end{array}$ & 0.031 \\
\hline $\begin{array}{l}\text { Mirizzi’s } \\
\text { syndrome }\end{array}$ & \multicolumn{2}{|l|}{ NA } & $>0.05$ \\
\hline $\begin{array}{l}\text { Pericholecystic } \\
\text { collection }\end{array}$ & NA & & $>0.05$ \\
\hline
\end{tabular}

The above table shows contracted GB and stone impaction at neck/cystic duct to be highly significant predictive factor followed by GB wall thickness. Mirizzi's syndrome and pericholecystic collection were not shown to be significant factors for conversion.

\section{Discussion}

Gall stone disease is indeed a very common disease and the incidence of the disease is on the rise. Cholecystectomy is the second most common operation performed in the United Kingdom, being only marginally exceeded by appendicectomy (Maingot 1774) ${ }^{1}$ and it remains the gold standard for treatment of gallstone disease. The classical open cholecystectomy is performed through 10 to $15 \mathrm{~cm}$ incision either through the Kocher's sub-costal incision or through the right para-median incision. Few of the disadvantages of classical open cholecystectomy are increased postoperative pain, ugly scar and increased recovery time as compared to laparoscopic cholecystectomy. Laparoscopy has seen maximum progress in the last decade. Laparoscopic cholecystectomy has now become the gold standard for the treatment of symptomatic gallstone disease. In VIMSAR, BURLA also it is one of the most common operations performed. The main aim of the study is to detect preoperative predictors and the rate of conversion of laparoscopic cholecystectomy to open cholecystectomy in our institute.

Laparoscopic cholecystectomy can be difficult in cases with dense adhesions and distorted anatomy. The various features that can increase the technical difficulty are adhesions in the Calot's triangle, distorted anatomy, empyema gallbladder, contracted gallbladder, Mirizzi's syndrome, previous upper abdominal surgery and acute cholecystitis. The conversion rates in various studies range from 1.5 to $35 \% .^{10-14 \text {, }}$

In this study 250 patients have been included in which clinical, biochemical and ultrasonographic parameters for predicting difficult laparoscopic cholecystectomy were analysed.

The various preoperative parameters in literature for predicting difficult laparoscopic cholecystectomy are: age, sex, acute attacks, previous upper abdominal surgery, jaundice, obesity, raised WBC, low albumin, gallstone size, gallbladder wall thickness, gallbladder volume, and number of stones, common bile duct size and stone impaction in the neck. Of these age $>65$ years, male sex, 
previous upper abdominal surgery, gallbladder wall thickness, contracted gallbladder and stone impaction shows the maximum correlation with difficult laparoscopic cholecystectomy and/or conversion of laparoscopic cholecystectomy to open cholecystectomy. ${ }^{2-9,11-14,}$

In this study out of 250 cases 18 got converted to open cholecystectomy with conversion rate of $7.2 \%$. This conversion rate is comparable to several other studies. ${ }^{11-14,}$

The age of the patients varied from $21-74$ years. The majority of patients were in the age group of $41-50$ years. The mean age was 41.9 years with standard deviation of 9.9. The conversion rate was highest in the age group of 51-60 years.

The conversion rate in the age group of $\geq 60$ years in this study was $100 \%$. So it is observed that with increasing age risk of conversion increases. However in this study, in multivariate logistic analysis age $\geq 65$ years was not found to be a significant predictor of conversion. The observed disparity may be due to less number of patients above 65 years of age in this study. H. J. J. van der Steeg et al (2011) found age more than 65 years to be significant independent predictive factors for conversion on multivariate logistic regression analysis.

Out of 250 patients, 39 were male and 219 were female. Male: Female ratio is 1: 5.62 which corroborates with the study of Ajay Anand et al (2007) who also found female preponderance. Out of 39 male 8 got converted which accounts for $20.5 \%$ of male patients whereas out of 219 female 10 got converted which accounts for $4.5 \%$ of female patients. From this we can conclude that conversion rate is 4.5 times higher in male patients in this study which corroborates with the study of H. J. J. van der Steeg et al (2011) and Volcan et al (2011).

Overall 46 out of 250 patients were predicted to be difficult cases based on clinical parameters out of which 30 were difficult on surgery and 18 out of all difficult cases got converted. Among the clinical parameters, male sex and acute cholecystitis were found to be significant predictors on multivariate logistic regression analysis. This corroborates with the study of H. J. J. van der Steeg et al (2011) who found male sex and acute cholecystitis to be significant independent predictive factors for conversion on multivariate logistic regression analysis. Volcan et al (2011) also found male sex to be the only statistically significant risk factor for conversion in their series.

In this study number of acute attacks more than two was not significant predictor for conversion on multivariate analysis which was found to be significant in the study of Wing-Hong Li et al (2009). ${ }^{9}$

Among clinical parameters previous upper abdominal operation was not found to be significant in this study. However, Fanaei S A et al (2009) found previous upper abdominal operation to be significant predictive factors. This disparity may be due lesser number of cases with upper abdominal operation in this study.

Out of 250 patients 13 patients were predicted to be difficult based on biochemical parameters of which 10 were difficult on surgery. Out of 10 difficult cases 4 got converted to open procedure. Amongst the biochemical parameters taken in this study, raised WBC count was the only significant preoperative predictor on multivariate logistic regression analysis which corroborates with the study of Jeremy M. Lipman et al (2007). Raised bilirubin was not significant in this study whereas Wing-Hong Li (2009) et al found raised bilirubin to be significant in their study. ${ }^{9}$

Raised alkaline phosphatase was not found significant in this study however Changiz Gholipour et al (2009) found it to be significant predictor in their study.

Out of 250 patients 30 were predicted to be difficult based on ultrasonographic parameters of which 23 were found to be difficult. Out of these 23 difficult cases 13 got converted to open procedure. In this study, a good correlation between gallbladder wall thicknesses with conversion to the open procedure was found which is in accordance with reports in other 
studies. ${ }^{4,5,}$ In study by Carmody E et al (1994), however, the opposite is reported.

This study shows that stone impaction at the gallbladder neck is a good predictor of conversion to the open procedure, which is contrary to the findings in other studies in which stone impaction is shown to have a moderate correlation. The main difficulty with stone impacted at the neck or Hartman's pouch is that it hinders holding of the gallbladder during dissection, and also due to impacted stone, the gallbladder is distended with mucus forming mucocele of the gallbladder, which is even more difficult to hold. In these cases, the gallbladder was emptied of its contents by aspirating the contents making the gallbladder more manageable.

The contracted gallbladder on ultrasonography was found to be significant predictive factor in multivariate logistic regression analysis in this study which corroborates with study of Pervez Iqbal et al (2008) who found contracted gallbladder to be significant. However pericholecystic collection and Mirizzi's syndrome was not found to be significant predictive factor in this study. This disparity was due to lesser number of cases.

Difficult dissection secondary to adhesions was the most common cause for difficult laparoscopic cholecystectomy and/or conversion to open cholecystectomy in this study. The other causes of conversion were short \& dilated cystic duct leading to inability to apply clips, bleeding from gallbladder bed and tear of cystic artery, tear of gallbladder with spillage of stones and bile. These various difficulties leading to operative time more than 90 minutes were taken as difficult cases. The laparoscopic cholecystectomy in expert hands should not take more than 45 to 50 minutes. . $^{6}$

The policy of our institute is early conversion if there is difficulty in progress in dissection of the Calot's triangle. This probably accounts for the high conversion rate in our study. Another reason for high conversion could be due to the reason that our patients usually are from the low socioeconomic group and come to seek medical advices only after years of neglect of the disease and after repeated attacks. Since these surgeries were done by surgeons experienced in laparoscopic cholecystectomy of our institute, therefore the learning curve statistics do not apply to this study. This study shows that preoperative clinical, biochemical and ultrasonographic parameters can predict operative difficulty for laparoscopic cholecystectomy to a good extent. These parameters can also aid in recognition of cases where an open cholecystectomy should be considered and the patient counselled preoperatively.

\section{Conclusion}

From this study, we can conclude that preoperative clinical, biochemical and ultrasonographic parameters are good predictors of difficulty in laparoscopic cholecystectomy in the majority of cases and should be used as a screening procedure. It can help surgeons to get an idea of the potential difficulty to be faced in a particular patient.

\section{References}

1. Bailey and Love: Short practice of surgery, $24^{\text {th }}$ Edition 1995; London, H. K. Lewis and co. Ltd.

2. Sanabria JR, Golliner S, Croxford R et al. Risk factors in elective laparoscopic cholecystectomy for conversion to open cholecystectomy. Jr Am Coll Surg 1994; 179: 696-703

3. Fried GM, Barkun JS, Sigman HH et al. Factors determing conversion to laparotomy in patients undergoing laparoscopic Cholecystectomy. Am Jr Surg 1994; 167: 35-41?

4. Sikora SS, Kumar A, Saxena R et al. Laparoscopic Cholecystectomy - Can conversion be predicted? World Jr Surg 1995; 19: 858-60.

5. Schrenk P, Woisetschlager R, Rieger R, Wayand WU A diagnostic score to predict the difficulty of a laparoscopic 
cholecystectomy from preoperative variables. Surg Endosc 1998; 12: 148-150.

6. Alponat A, Kum CK, Koh BC et al. Predictive factors for conversion of laparoscopic cholecystectomy. World $\mathrm{Jr}$ Surg 1997; 21:629-33.

7. Kama NA, Doganay M, Dolapci M, Reis E, Atli M, Kologlu M. risk factors resulting in conversion of laparoscopic cholecystectomy to open surgery. Surg Endosc 2001 Sept; 15(9):965-8.

8. Tayeb M, Raza SA, Khan MR, Azami R: Conversion from laparoscopic to open cholecystectomy: Multivariate analysis of preoperative risk factors. J Postgrad Med 2005, 51:17-20

9. Wing-Hong Li, Colin Wai-Ho Chu and Moon-Tong Cheung. Factors for conversion in laparoscopic cholecystectomy for acute cholecystitis: Is timing important?: Surgical Practice (2009) 13, 42-47

10. Grace P, Qureshi A, Darzi A, et al. Laparoscopic cholecystectomy, a hundred consecutive cases. Jr Med J 1991: 84: 124.

11. Cushieri A, Duboisf, Mouiel J, et al. The European experience with laparoscopic cholecystectomy. Am J Surg 1991; 161: 385-7

12. Davis C, Arrengani M, Nagan R, et al. Laparoscopic cholecystectomy: The St. Vincent experience. Surg Laparosc Endosc 1992; 2:64-9

13. Chang Mau Lo, Chi Leung, et al. Prospective randomized randomized study of Early versus Delayed Laparoscopic cholecystectomy for acute cholecystitis. Annals of Surgery 1998; 227: 4: 461-467

14. Deitch EA, Utility and accuracy of ultrasonographically measured gallbladder wall as diagnostic criteria in biliary tract disease. Dig Dis Sci 1981;26: 868-93.

15. Knight JS, Mercer SJ, Somers SS, Walters AM, Sadek SA, Toh SK.Timing of urgent of laparoscopic cholecystectomy does not influence conversion rate. $\mathrm{Br} \mathrm{J}$ Surg 2004;91:601-4.

16. Lindner H. Embryology and anatomy of the biliary tree. In: Way LW, Pellegrini CA (eds) Surgery of the Gallbladder and Bile Ducts. Philadelphia: Saunders, 1987:3-4, 7-8.

17. Bismuth H. Surgical anatomy and anatomical surgery of the liver. In: Blumgart LH (ed) Surgery of the Liver and Biliary Tract, 2nd Ed. Edinburgh: Churchill Livingstone, 1994:3-7.

18. Rappaport AM. Anatomic considerations. In: Schiff L (ed) Diseases of the Liver, 4th Ed. Philadelphia: Lippincott, 1975.

19. Cantlie J. On a new arrangement of the right and left lobes of the liver. $J$ Anat Physiol (Lond) 1898; 32: IV.

20. Healy JE Jr. Clinical anatomic aspects of radical hepatic surgery. J Int Coll Surg 1954; 22:542.

21. Chenderovitch J. Les conceptions actielles des mecanismes de la secrection biliarie. Presse Med 1963; 71:2645.

22. Hicken NF, Coray QB, Franz B. Anatomic variations of the extrahepatic biliary system as seen by cholangiographic studies. Surg Gynecol Obstet 1949; 88:577.

23. Rappaport AM. Hepatic blood flow: morphologic aspects and physiologic regulation. In: Javitt ND (ed) Liver and Biliary Tract Physiology. Int Rev Physiol 1980:21.

24. Anson BJ, McVay CB. Surgical Anatomy, 5th Ed. Philadelphia: Saunders, 1971:597.

25. Smadja C, Blumgart LH. The biliary tract and the anatomy of biliary exposure. In Blumgart LH (ed) Surgery of the Liver and Biliary Tract, 2nd Ed. Edinburgh: Churchill Livingstone, 1994:11-16.

26. McIndoe AH, Counseller VS. A report on the bilaterality of the liver. Arch Surg 1927; 15:589. 
27. Thaler MM, Way LW. The biliary tract. In: Sleisenger MH, Fordtran JS (eds) Gastrointestinal Disease. Philadelphia: Saunders, 1978:1245.

28. Hjortsjo $\mathrm{CH}$. The topography of the intrahepatic duct systems. Acta Anat (Basel) 1951; 11:599.

29. Meyers WC, Jones RS. Anatomy. In: Textbook of Liver and Biliary Surgery. Philadelphia: Lippincott 1990; 18.

30. Goss CM (ed). Gray's Anatomy, 29th American Ed. Philadelphia: Lea \& Febiger, 1974.

31. Rex H. Beitrage zur Morphologie der Saugerleber. Morphol Jahrb 1888; 14:517.

32. Higgins GM. The biliary tract of certain rodents with and those without a gallbladder. Anat Rec 1926; 32:89.

33. Schulenberg CAR. Anomalies of the biliary tract as demonstrated by operative cholangiography. Med Proc 1970; 16:351.

34. Muirhead WR, O'Leary JP. Calot's triangle: loose interpretation or respectful accuracy? Am Surg 1999; 65(2):186-187.

35. Nahrwold DL. The biliary system. In: Sabiston DC (ed) Textbook of Surgery. Philadelphia: Saunders, 1968:1128.

36. Sekimoto M, Tomita N, Tamura S, et al. New retraction technique to allow better visualization of Calot's triangle during laparoscopic cholecystectomy. Surg Endosc 1998;12:1439-1441.

37. Hugh TB, Kelly MD, Mekisic A. Rouviere's sulcus: a useful landmark in laparoscopic cholecystectomy. Br J Surg 1997; 84(9):1253-1254.

38. Jacobson JB, Brody PA. The transverse common duct. AJR 1981; 136:91.

39. Hollinshead HW. The liver and the gallbladder. In: Anatomy for Surgeons, 3rd Ed. New York: Hoeber-Harper, 1982.
40. Job TT. The anatomy of the duodenal portion of the bile and pancreatic ducts. Anat Rec 1926; 32:212.

41. Boyden EA. The sphincter of Oddi in man and certain representative mammals, Surgery (St. Louis) 1937; 1:25.

42. Keddie NC, Taylor AW, Sykes PA. The termination of the common bile duct. $\mathrm{Br} \mathrm{J}$ Surg 1974;61:623.

43. Linder HH, Pena VA, Ruggieri RA. A clinical and anatomical study of anomalous termination of the common bile duct into the duodenum. Ann Surg 1976;184:626.

44. Michels NA. Newer anatomy of the liver and its variant blood supply and collateral circulation. Am J Surg 1966; 112:337?

45. Charnsangavej C, Chuang VP. Angiography classification of hepatic arterial collaterals. Radiology 1982; 144:485.

46. Johnston EV, Anson BJ. Variations in the formation and vascular relationships of the bile ducts. Surg Gynecol Obstet 1952; 94:669.

47. Nakamura S, Tsuzuki T. Surgical anatomy of the hepatic veins and the inferior vena cava. Surg Gynecol Obstet 1981; 152:43.

48. Mall FP. A study of the structural unit of the liver. Am J Anat 1906; 5:227?

49. Mallet-Guy P, et al. Recherches experimentales sur la circulation lymphatique due fofie. I. Donnes immediate sur la permeabilite biliolymphatique. Lyon Chir 1962;58: 847.

50. Liu C, et al. Factors affecting conversion of laparoscopic cholecystectomy to open surgery. Arch Surg 1996; 131:98-101. 